\title{
"Do Islamic banks contribute to growth of the economy? Evidence from United Arab Emirates (UAE)"
}

\begin{tabular}{|c|c|c|}
\hline AUTHORS & \multicolumn{2}{|c|}{$\begin{array}{l}\text { Mosab I. Tabash (D https://orcid.org/0000-0003-3688-7224 } \\
\text { Suhaib Anagreh (D https://orcid.org/0000-0003-1751-7674 }\end{array}$} \\
\hline ARTICLE INFO & \multicolumn{2}{|c|}{$\begin{array}{l}\text { Mosab I. Tabash and Suhaib Anagreh (2017). Do Islamic banks contribute to } \\
\text { growth of the economy? Evidence from United Arab Emirates (UAE). Banks and } \\
\text { Bank Systems, 12(1-1),113-118. doi:10.21511/bbs.12(1-1).2017.03 }\end{array}$} \\
\hline DOI & \multicolumn{2}{|c|}{ http://dx.doi.org/10.21511/bbs.12(1-1).2017.03 } \\
\hline RELEASED ON & \multicolumn{2}{|l|}{ Tuesday, 25 April 2017} \\
\hline RECEIVED ON & \multicolumn{2}{|l|}{ Saturday, 28 January 2017} \\
\hline ACCEPTED ON & \multicolumn{2}{|l|}{ Monday, 20 March 2017} \\
\hline & \multicolumn{2}{|c|}{$((c))$ EY-NC } \\
\hline LICENSE & \multicolumn{2}{|c|}{$\begin{array}{l}\text { This work is licensed under a Creative Commons Attribution-NonCommercial } 4.0 \\
\text { International License }\end{array}$} \\
\hline JOURNAL & \multicolumn{2}{|l|}{ "Banks and Bank Systems" } \\
\hline ISSN PRINT & \multicolumn{2}{|l|}{$1816-7403$} \\
\hline ISSN ONLINE & \multicolumn{2}{|l|}{$1991-7074$} \\
\hline PUBLISHER & \multicolumn{2}{|c|}{ LLC "Consulting Publishing Company "Business Perspectives" } \\
\hline FOUNDER & \multicolumn{2}{|c|}{ LLC “Consulting Publishing Company "Business Perspectives” } \\
\hline \multirow{2}{*}{ NUMBER OF REFERENCES } & & 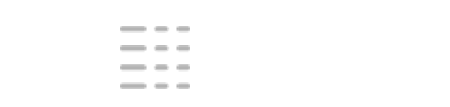 \\
\hline & NUMBER OF FIGURES & NUMBER OF TABLES \\
\hline 26 & 2 & 8 \\
\hline
\end{tabular}

(c) The author(s) 2023. This publication is an open access article. 
Mosab I. Tabash (UAE), Suhaib Anagreh (UAE)

\title{
Do Islamic banks contribute to growth of the economy? Evidence from United Arab Emirates (UAE)
}

\begin{abstract}
Islamic finance has grown rapidly in the recent years particularly in the Middle East and the world. It receives a great attention of bankers and financial scholars due to its stability during financial shocks and crises. The paper uses empirical analysis to test the role of Islamic banking in enhancing the economic growth of United Arab Emirates (UAE). Gross Domestic Product (GDP), Gross formation (GF), and Foreign Direct Investment (FDI) are used as representatives for economic growth, while Islamic banks' investments are used as a representative for Islamic financial sector in the UAE. The study uses time series techniques to test the link between the variables. In the current study, co-integration along with error correction models is utilized. All econometric work is done using Eviews. The findings reveal that the causal relationship between Islamic banks' investments and economic growth of UAE is supply-leading direction. Furthermore, the findings depict that Islamic investments have contributed in increasing investments and in bringing FDI into the country in the long-term. The study also shows that there is two-way association between Islamic banks' investments and FDI. It shows that FDI supports Islamic banking and Islamic banking brings FDI. The paper concludes that authorities of the UAE should devote more attention for this growing banking sector by facilitating regulations for establishing new Islamic banks and then creating a suitable environment for their growth and progress in the UAE.
\end{abstract}

Keywords: Islamic banking, investments, economic growth, cointegration, UAE.

JEL Classification: O16, C32.

Received on: $28^{\text {th }}$ of January, 2017.

Accepted on: $20^{\text {th }}$ of March, 2017.

\section{Introduction}

Islamic banking has emerged as an effective tool for funding projects globally. Most of financial institutions and centres are finding clear insights that Islamic finance has already been moving side by side within the global financial system. Islamic finance has the ability to contribute and to meet the challenges of ending poverty and boosting prosperity (World Bank, 2015).

Islamic banking is one of the fastest emerging sectors in the last years. The Islamic finance sector has growing fast over the years, growing at $15-20 \%$ annually. Nowadays, assets of Islamic finance are close to US \$2 trillion for all different sectors of the industry (World Bank report, 2015). Islamic banks are playing a positive role in enhancing economic growth in the developing countries due to its distinctive characteristics (Tabash and Dhankar, 2014).

Financial system and banking play an important role in economic activities in all countries. The flow of funds between lenders, investors and borrows creates the cycle of production and progress in the society. The banking sector constitutes about $80 \%$ of the total transactions in the Middle East and is considered a major component in the economic

(c) Mosab I. Tabash, Suhaib Anagreh, 2017.

Mosab I. Tabash, Assistant Professor of Finance, College of Business, Al Ain University of Science and Technology, United Arab Emirates (UAE).

Suhaib Anagreh, Assistant Professor of Finance, College of Business, Al Ain University of Science and Technology, United Arab Emirates (UAE).

This is an Open Access article, distributed under the terms of the Creative Commons Attribution-NonCommercial 4.0 International license, which permits re-use, distribution, and reproduction, provided the materials aren't used for commercial purposes and the original work is properly cited. growth and then economic development. The Middle East markets have recognized that Islamic banking alternative has become increasingly attractive among the investment community, corporate end users, consumers and intermediaries, particularly after global financial crisis in 2008 .

The association between the financial sector and economic growth received much debate in the literature. There are three causal relationships between the financial development and economic growth that have been found. The first one is supply-leading which means that the financial sector is a vital factor for the progress of economic growth (Patrick, 1966). The second one is demand following which means the financial development is a result of the development of the real sector (Herms and Lensink, 1996). The third link between them is a bidirectional relationship. Many financial analysts have said that the efficiency of the financial sector is connected to the growth of the economy in any country. One of the empirical studies done by Tabash and Dhankar (2015) concluded a strong association between Islamic finance and economic growth in different countries of Gulf Cooperation council (GCC).

In spite of the considerable spread of Islamic banking sector, most of the work done in this area is theoretical basis. In this study, we try to do something different from the previous work. Therefore, we empirically examine the associations between the development of Islamic financial sector and growth of the economy in one of highly emerging economy in the Middle East and the world, which is the UAE. We encourage policy makers, financial scholars and investors to look into 
the results of this study and try to develop strategies, investments and plans to benefit of this growing financial sector. This study contains six sections as follows. Introduction provides an overview about Islamic finance industry. Section 1 gives a picture about current status of Islamic finance in the UAE. Section 2 covers the literature review. Section 3 covers the methodology. Section 4 outlines the results. Final section presents the conclusion.

\section{Islamic banking in UAE}

Islamic banking in the Middle East and North African (MENA) has now considered as an integral part in the developments of any country. It meets the financial needs of people without conflicting with their religious values and beliefs.

The banking sector of UAE, the biggest banking sector in the GCC by total assets, continued its positive growth rate in 2008 (World Fact Book, 2014). Two new Islamic banks (Dubai based Noor Islamic bank, and Abu Dhabi based Al Hilal Islamic bank) were established in the UAE in 2007 and 2008. There appered some new heights in the United Arab Emirates (UAE) when we are looking at the development of Islamic banking into the country in the last years (Emirates diary, 2015).

Islamic banks assets increased by $15 \%$ in 2015 , reaching AED 464 billion, with their share in total assets increased from $18 \%$ at the end of 2014 to $19 \%$ at the of
2015. At the same time, their investments rose by $15.0 \%$, reaching AED 307 billion, or $22.0 \%$ of domestic credit (Central Bank report, 2015).

It is shown from Table (1) that the assets of Islamic banks of UAE increased from 405 billion at the end of 2014 to 464 billion at the end of 2015 with annual growth rate is $15 \%$. At the same time, the Islamic investments also jumped from 266 billion to 307 with annual percentage rate equal to $15.0 \%$. Further, the Islamic banks assets in the UAE rose to greater than US \$ 70,000 million in 2014 from US \$ 1 million in the year of 1990 with a cumulative growth rate $98.57 \%$, as appeared in figure 1. Currently, there are 45 banks working in UAE. 23 out of 45 are national banks, while other 22 banks are foreign banks. There are 8 full-fledged Islamic banks, out of 23 national banks, working under Shariah principles and the other banks have mixed banking operations (Emirates diary, 2015).

Table 1. Assets of Islamic banks in UAE (2014-2015)

\begin{tabular}{|l|c|c|}
\hline & $\begin{array}{c}2014 \\
\text { (AED billions) }\end{array}$ & $\begin{array}{c}2015 \\
\text { (AED billions) }\end{array}$ \\
\hline & Q4 & Q4 \\
\hline Assets & 405 & 464 \\
\hline Percent of total asset banking & 18.0 & 19.0 \\
\hline Islamic investments & 266 & 307 \\
\hline Percent of domestic credit & 21.0 & 22.2 \\
\hline
\end{tabular}

Source: Central Bank of the UAE report.

Islamic financial investment

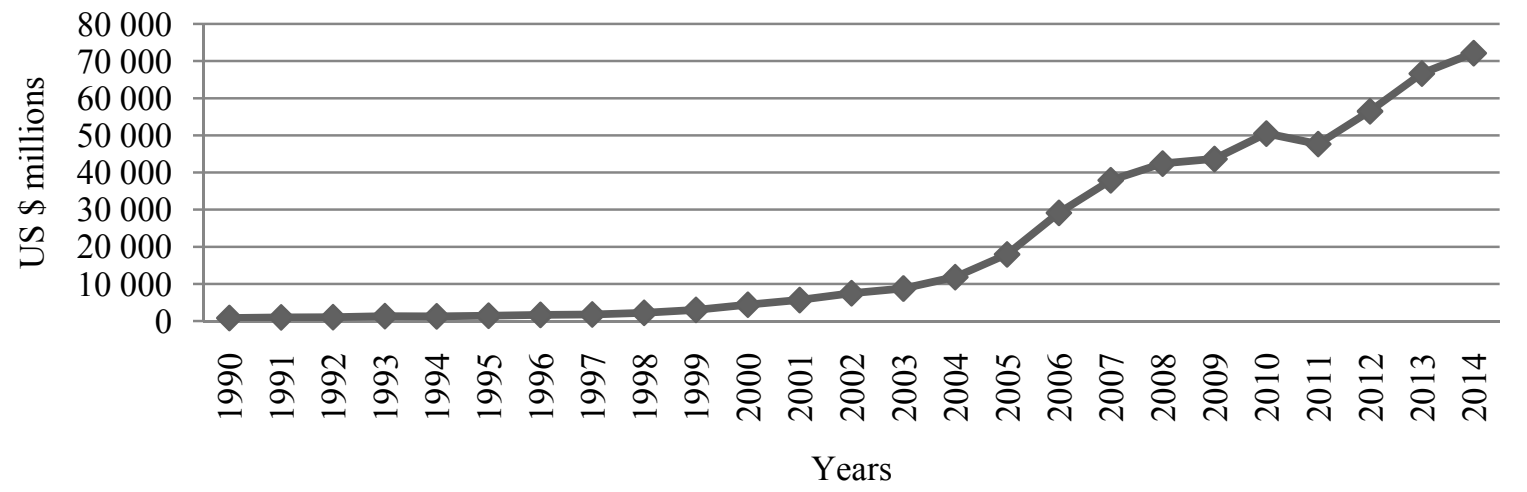

Fig. 1. Islamic financial investments in UAE (1990-2014)

\section{Literature review}

The link between the progress of financial system and economic growth was considered as the most debated issue in the literature to examine, whether the financial sector participates in the growth of real sector or not. Schumpeter (1934), Goldsmith (1969), McKinnon (1973), Shaw (1973), King and Levine (1993) and some other authors have affirmed that finance has an important element of growth, while Robinson (1952), Lucas (1988) and others have concluded it is only a minor growth factor.
Bashir and Hasan (2003) have discussed the relationship between financial development and economic growth in selected countries of Middle East. They used econometric models in their study. They found the size of the financial system affected its economic growth and had a great impact on it. Their findings are consistent with other studies done by King and Levine (1993).

In another study done by Beck and Levine (2004), they studied the effect of stock markets and banks on the growth of the economies of selected countries of the world covering the period 1976-1998. They 
used panel data analysis and different econometric analysis techniques. Their findings support the hypothesis that financial sector is vital for economic growth for the countries under the study. In 2005 Abu-Bader and Abu Qarn (2005) tested the causal association between financial sector and growth of the economy in Egypt for 1960-2001. They utilized granger causality tests. They concluded that there is a strong relation between the financial sector and economic growth through mobilizing investments and gross formation in Egypt.

Further, Kar et al. (2011) on his study have selected some developing countries to test the casual relationship between financial development and economic growth. They used time series analysis for the period covering 1980-2007. Their study sample includes countries of the Middle East and North Africa. They concluded that economic growth is a function of financial development in the countries under the study.

In the same year, Bangake and Eggoh (2011) confirmed the viewpoint of existing bi-directional causality between the financial sector progress and the development of the economy in emerging economies. They selected many countries from all parts of the world. Their sample consisted of 71 countries covering the period 1960-2004. They used different econometric modelling techniques. Their findings support the idea that each sector affected the other, i.e., the relationship between the financial development and economic growth is bi-directional.

The studies in the context of Islamic banking and economic growth are limited. For example, Furqani and Mulyany (2009) in their study tested the link between Islamic finance and economic growth for Malaysia. They used methods of cointegration under the period 1997-2005 to test the link between the variables. They found that there is a bi-directional relationship between Islamic banking and long-term investment in Malaysia. In the short run, however, they found that Islamic banking granger cause the investment to develop in Malaysia. A more recent study on Indonesia by Abduh and Omar (2012) also has confirmed the view that there is a bi-directional association between Islamic banking development and economic growth in Indonesia.

At the same year, Tajgardoon and Noormohamadi (2012) examined the causality link between FDI and Islamic banking. They concluded that there is no cointegration found between FDI and Islamic banking in nine countries from Organization Islamic Conference (OIC) during the period 1995-2010. Their findings affirm that there is a bi-directional relationship between the variables. It means that FDI reinforces Islamic banking and Islamic banking attracts FDI. Among the limited studies conducted on this area, we try to test the relationship between Islamic banks' investments and economic growth of UAE using econometric analysis. The study questions are formulated as follows.

1. Are there any relationships between Islamic banks' investments and growth of the economy in the UAE?

2. Does Islamic banks' investments granger cause the economic growth in the UAE and its direction?

\section{Research methodology}

3.1. Variables, sources and data collection. We are using four variables to test the relation between Islamic banks investments and growth of the economy of UAE. Islamic banks investments' are chosen to represent the Islamic financial sector while Gross Domestic Product (GDP), Gross formation (GF) and Foreign Direct Investments (FDI) are chosen to represent the economic sector growth.

We use different databases to fetch the required data to test the relationships between variables. World Bank, International Monetary Funds (IMF), and Islamic banks and financial intuitions databases are used. Different time periods are taken for all variables due to availability of data. The relation between the variables is shown in Figure (2).

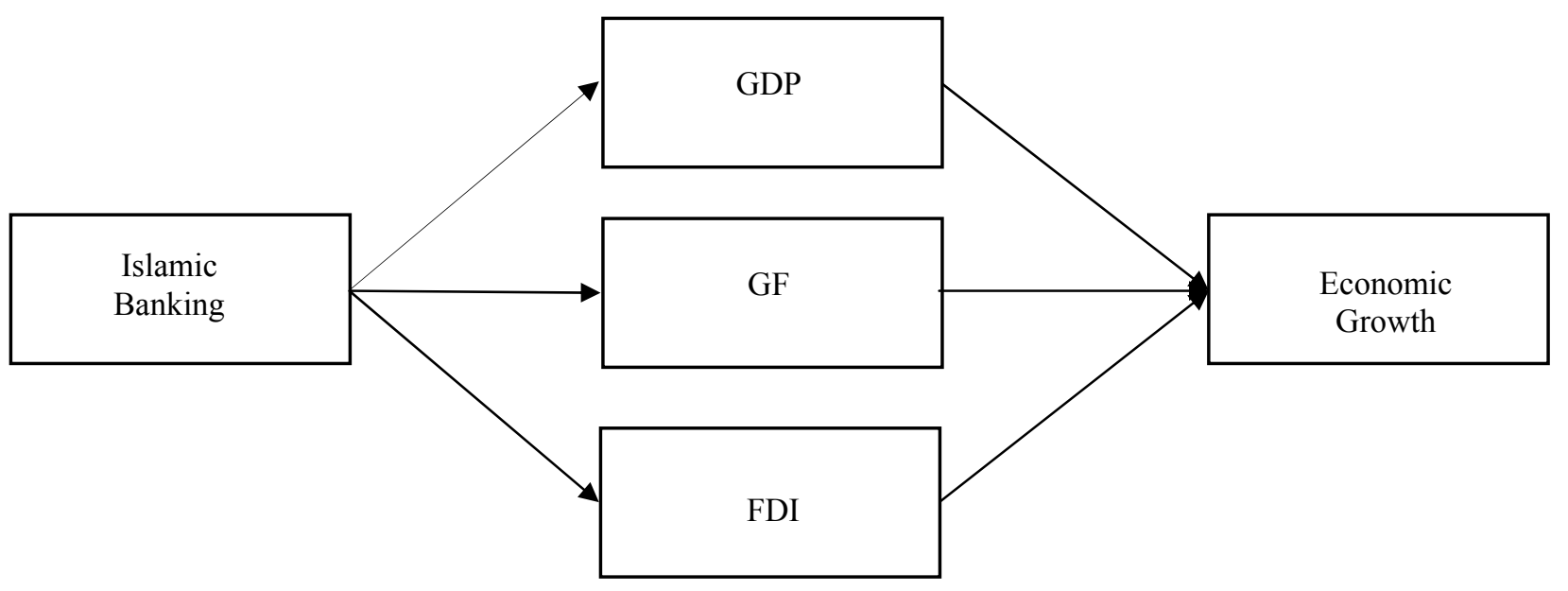

Fig. 2. Study variables 
The econometric analysis is done by Eviews. Logarithms of time series were taken to void errors between series.

3.2. Johansen co-integration test and error correction model (ECM). The co-integration procedure tests if the long-term association exists between variables or not. Johansen and Juselius in 1990 extended the cointegration work to include two important test statistics, which called the trace and the maximal eigenvalue tests to find and explore, how many co-integrating vectors exist between variables. This means that, if $y_{t} \sim \mathrm{I}$ (1) and $x_{t} \sim \mathrm{I}(1)$ then $\varepsilon_{t} \sim \mathrm{I}(0)$, so $y_{t}$ and $x_{t}$ are cointegrated. It has also a co-integration relationship as, $y_{t}=\beta x_{t}+\varepsilon_{t}$, moreover, if $\varepsilon_{t}$ error term is stationary (I (0)), then the variables are cointegrated and the following hypothesis is stated.
$\mathrm{H}_{0}: \beta=0$ (no co-integration is found)

$\mathrm{H}_{1}: \beta \neq 0$ (co-integration isfound)

If we reject the null hypothesis, it means we accept $\mathrm{H}_{1}$ which means there is a long-term co-integration between variables. To test it, maximum Eigen and Trace statistics are used. If there is association between variables, then we can proceed to error correction model (ECM) as stated in the below equations. The number of lags in the model is chosen by the lowest Akaike information criterion (AIC) before the selected model is implemented by (OLS). Following the research works done by Odhiambo (2011) and Narayan (2008), we get the short-run parameters by estimating ECM associated with the long-run estimates. Short-run relationship can be derived by construction an ECM of the following forms.

$$
\begin{aligned}
& \Delta \operatorname{In} G D P=\alpha_{0}+\sum_{i=1}^{k} \alpha_{1} \Delta \operatorname{In} G D P_{t-1}+\sum_{i=0}^{k} \alpha_{2} \Delta \operatorname{In} G D P_{t-1}+\delta E C T_{t-1}+\varepsilon_{t}
\end{aligned}
$$

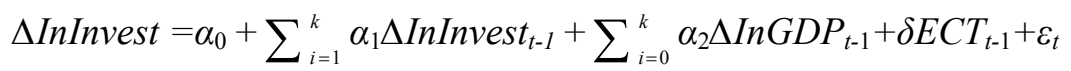

$$
\begin{aligned}
& \Delta I n G F=\alpha_{0}+\sum_{i=1}^{k} \alpha_{1} \Delta I n G F_{t-1}+\sum_{i=0}^{k} \alpha_{2} \Delta \text { InInvest }_{t-1}+\delta E C T_{t-1}+\varepsilon_{t} \\
& \Delta I n F D I=\alpha_{0}+\sum_{i=1}^{k} \alpha_{1} \Delta \operatorname{InFDI}_{t-1}+\sum_{i=0}^{k} \alpha_{2} \Delta \text { InInvest }_{t-1}+\delta E C T_{t-1}+\varepsilon_{t}
\end{aligned}
$$

where:

$\Delta$ : The first difference

$\alpha_{S}^{\prime}$ : Short run coefficients

$\delta$ : The speed of adjustment

$\mathrm{k}_{\mathrm{i}}(1,2)$ : \# of lags

3.3. Granger causality test. The work of Granger (1987) lies in the idea that if the two variables are co-integrated, then dynamic relationships are found between them. Granger suggested a time-series data based approach in order to find causality. The equations for granger causality test can be written as shown in equations 5 and 6 .

$X_{t}=\alpha_{0}+\sum \beta_{j} X_{t-j}+\sum \oint_{i} Y_{t-i}+u_{1 t}$

$Y_{t}=\alpha_{0}+\sum \beta_{j} X_{t-j}+\sum \emptyset_{i} Y_{t-j}+u_{2 t}$

$u_{1 t}$ and $u_{2 t}$ are uncorrelated error terms.

\section{Analysis, results and discussions}

4.1. Descriptive analysis. We can observe from Table 2 that the highest value for Islamic banks' investments in 2014 reached $(399,451.0)$ from $(50,701.00)$ in 1990 with standard deviation of (121.0863). This informs us an impression of huge progress in Islamic banking industry recently. The findings depict that the median for GDP, GF, FDI, and Islamic banks' investments is lower than the mean which indicates that the values are skewed to the left.
Table 2. Summary statistics

\begin{tabular}{|l|c|c|c|c|}
\hline \multicolumn{1}{|c|}{ Statistics } & $\begin{array}{c}\text { GDP (US \$ } \\
\text { millions) }\end{array}$ & $\begin{array}{c}\text { GF (US \$ } \\
\text { millions) }\end{array}$ & $\begin{array}{c}\text { FDI (US \$ } \\
\text { millions) }\end{array}$ & $\begin{array}{c}\text { Islamic investments } \\
\text { (US \$ millions) }\end{array}$ \\
\hline Mean & $170,545.6$ & $78,247.57$ & $3,954.100$ & $20,699.84$ \\
\hline Median & $109,816.0$ & $68,124.50$ & 401.8000 & $7,469.000$ \\
\hline Maximum & $399,451.0$ & $97,192.00$ & $14,187.0$ & $72,123.00$ \\
\hline Minimum & $50,701.00$ & $22,433.00$ & -985.3400 & 787.000 \\
\hline Std. deviation & $121,086.3$ & $27,403.27$ & $5,269.40$ & $23,786.49$ \\
\hline Observations & 25 & 14 & 25 & 25 \\
\hline
\end{tabular}

4.2. Stationary test. It is clear from Table 3 the variables are stationary at first difference. We can notice that the $P$ value is $(0.0<0.05)$ level of significance for GDP in the PP test. It means that the series is stationary.

Table 3. Stationary test

\begin{tabular}{|l|c|c|c|c|}
\hline \multirow{2}{*}{$\begin{array}{c}\text { Study } \\
\text { variables }\end{array}$} & \multicolumn{2}{|c|}{ ADF } & \multicolumn{2}{c|}{$\mathrm{PP}$} \\
\cline { 2 - 5 } & $\mathrm{I}(0)$ & $\mathrm{I}(1)$ & $\mathrm{I}(0)$ & $\mathrm{I}(1)$ \\
\hline \multirow{2}{*}{$(\mathrm{GDP})$} & -2.129650 & $-3.371806^{\star *}$ & $-3.912820^{\star * *}$ & $-6.843615^{\star *}$ \\
& 0.0548 & 0.0063 & 0.0016 & 0.0000 \\
\hline \multirow{2}{*}{ (Invest) } & -2.230133 & $-3.491446^{\star *}$ & $-3.528268^{\star * *}$ & $-7.164665^{\star *}$ \\
& 0.0454 & 0.0048 & 0.0036 & 0.0000 \\
\hline \multirow{2}{*}{ (GF) } & -1.771436 & -2.141708 & -2.141708 & $-11.68149^{* *}$ \\
& 0.5985 & 0.4471 & 0.4471 & 0.0010 \\
\hline \multirow{2}{*}{ (FDI) } & -1.284754 & $-3.382949^{* *}$ & -1.399840 & $-3.387763^{* *}$ \\
& 0.6157 & 0.0251 & 0.5616 & 0.0250 \\
\hline \multirow{2}{*}{$* * *$} & & & \\
\hline
\end{tabular}

Sig. at: ${ }^{*} 10,{ }^{* *} 5$ and ${ }^{* * *} 1$ percent level.

The same picture can be seen for (Invest), the $p$ value is $(0.0048<0.05)$ level of significance in $\mathrm{ADF}$ test. Further, for (Gf), the $\mathrm{p}$ value is $(0.001<0.05)$ in PP test. It means that the GF series is stationary. Finally, the $\mathrm{P}$ value for FDI is 
$(0.0251<0.05)$ in ADF test which means the series is stationary. These results recommend us to go further to cointegration test.

4.3. Johansen co-integration test and error correction model (ECM). It is clear from Table 4 that the findings of Johansson test for the long-term relation between variables. For GDP, the trace statistics (16.52450) is more than (15.41) critical bound value. Similarly, the result is found for GF in which the trace statistics (25.63250) is more than (15.41) critical bound value. Furthermore, the trace statistics (18.46340) is greater than (5.41) critical bound value for FDI. The findings affirm the existence of a longterm association between the study variables.

Table 4. Trace test

\begin{tabular}{|c|c|c|c|c|}
\hline \multirow{2}{*}{\multicolumn{2}{|c|}{ Variables }} & \multirow{2}{*}{$\begin{array}{c}\text { Trace } \\
\text { values }\end{array}$} & \multicolumn{2}{|c|}{ Bound critical values* } \\
\hline & & & $5 \%$ & $1 \%$ \\
\hline \multirow[t]{2}{*}{ (GDP) } & $\#$ of cointegration vector $=0$ & $16.52450^{* *}$ & 15.41 & 20.04 \\
\hline & $\#$ of cointegration vector $\geq 1$ & 0.589390 & 3.76 & 6.65 \\
\hline \multirow[t]{2}{*}{ (GF) } & $\#$ of cointegration vector $=0$ & $25.63250^{* *}$ & 15.41 & 20.04 \\
\hline & $\#$ of cointegration vector $\geq 1$ & $6.931015^{\star \star}$ & 3.76 & 6.65 \\
\hline \multirow{2}{*}{ (FDI) } & $\#$ of cointegration vector $=0$ & $18.46340^{* *}$ & 5.41 & 20.04 \\
\hline & $\#$ of cointegration vector $\geq 1$ & 3.264970 & 3.76 & 6.65 \\
\hline
\end{tabular}

The results for Max-Eigenvalue test are shown in Table 5. The same picture is found for co-integration between variables, for GDP, the eigenvalue test statistics (15.93515) is higher than (14.07) bound critical value. The test value for GF is (18.70135) and it is higher (14.07) bound critical value.

Table 5. Max-Eigenvalue test

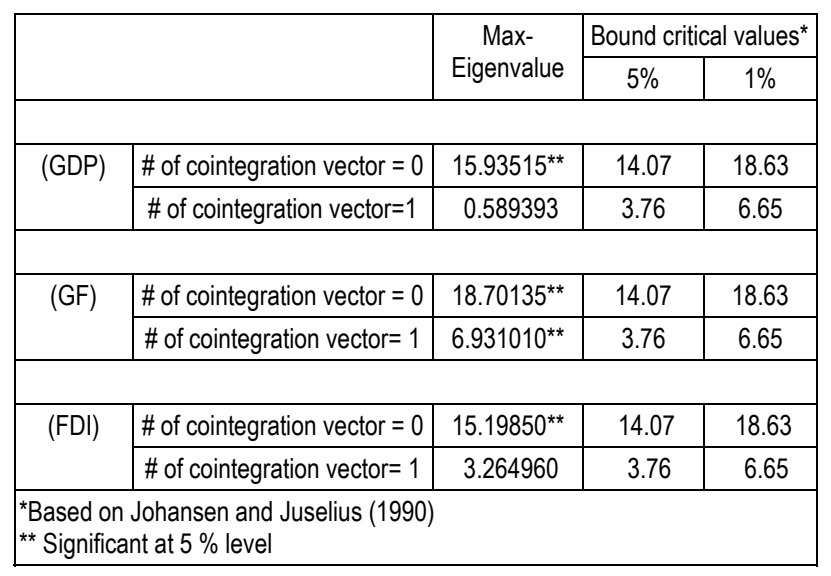

The test value for FDI is (15.19850) and it is greater than (14.07) bound critical value. It is clear from the results of Table 4 and Table 5 that there is a long-term association between variables. And in order to find more insights into the casual relationship between Islamic financial investments and economic growth, ECM test is done. Error correction model results are reported in Table 6. It is clear from Table 6 that the error correction parameters for the (1-4) equations are negatively correlated which assures the existence of causality in one direction between variables.

Table 6. Error correction model

\begin{tabular}{|c|c|c|c|c|}
\hline Coefficient & $\triangle L I n G D P$ & $\Delta L n d G F$ & $\Delta$ InInvest & $\Delta / n F D I$ \\
\hline$E C T_{t-1}$ & $\begin{array}{l}-0.228710 \\
(0.0150)^{* *}\end{array}$ & $\begin{array}{l}-0.070565 \\
(0.0368)^{\star *}\end{array}$ & $\begin{array}{l}-0.173265 \\
(0.0232)^{* *}\end{array}$ & $\begin{array}{l}-0.121845 \\
(0.0414)^{* *}\end{array}$ \\
\hline$\Delta / n$ invest & $\begin{array}{c}0.41325 \\
(0.0340)^{\star *}\end{array}$ & $\begin{array}{l}0.350317 \\
(0.0974)^{*}\end{array}$ & --- & $\begin{array}{l}0.450217 \\
(0.0865)^{*}\end{array}$ \\
\hline$\Delta / n g d p$ & -- & ---- & $\begin{array}{c}0.678990 \\
(0.042147)^{\star *}\end{array}$ & --- \\
\hline$\Delta / n d i$ & --- & --- & $\begin{array}{c}0.524589 \\
(0.0314527)^{\star *}\end{array}$ & --- \\
\hline
\end{tabular}

The error correction coefficients show the speed of adjustment to back to equilibrium after shock is low. The positive sign coefficients of Islamic financial parameters in equations (1)-(4) supported the view that Islamic investments could positively affect the economic growth, business formation and FDI. In order to meet the normal estimates of ordinary least square model, diagnostic tests are applied to the ECM. The models passed all the diagnostic tests against serial correlation (Breusch-Godfrey test), heteroscedasticity (white heteroscedasticity test), and normality (JarqueBera test) as shown in Table 7.

Table 7. Diagnostics tests results

\begin{tabular}{|l|c|}
\hline & P value \\
\hline Breusch-Godfrey test serial correlation & 0.480955 \\
\hline F-Arch test & 0.820629 \\
\hline white heteroscedasticity test & 0.116424 \\
\hline (Jarque-Bera test), Normal & 0.459063 \\
\hline
\end{tabular}

4.4. Granger causality results. It is clear from Table (8) that the $p$ value $(.01526<.05)$ which indicates that the Islamic investments causes the economic sector of UAE to grow and progress. The same picture is drawn for gross formation and Islamic banks' investments since 0.03205 is lower than 0.05 , which means that Islamic investments causes many institutions to establish and enter the economy.

Table 8 . Granger causality results

\begin{tabular}{|l|c|l|c|c|}
\hline \multicolumn{3}{|c|}{ The direction of causality } & F statistics & P value \\
\hline Invest & $\longrightarrow$ & GDP & 5.41616 & $0.01562^{* *}$ \\
\hline GDP & $\longrightarrow$ & Invest & 2.02775 & 0.16844 \\
\hline GF & $\longrightarrow$ & Invest & 7.01766 & 0.07391 \\
\hline Invest & $\longrightarrow$ & GF & 13.3611 & $0.03205^{* *}$ \\
\hline Invest & $\longrightarrow$ & FDI & 12.8782 & $0.008^{* *}$ \\
\hline FDI & $\longrightarrow$ & Invest & 6.93100 & $0.028^{* *}$ \\
\hline ** Significant at 5 \% level & \multicolumn{5}{|l}{} \\
\hline
\end{tabular}

Furthermore, the causality relationship between FDI and Islamic banks' investments is bidirectional since $(0.008<0.05), \quad(0.028<.05)$. It means that UAE have an efficient banking system 
and a dynamic economy, which creates a good atmosphere for foreign direct investment and through foreign direct investment come in home economy.

\section{Conclusion}

The results affirm that the Islamic financial sector leads the growth of the economy in the UAE in terms of GDP, GF, and FDI. This means that Islamic financial system is an efficient financial system that improves the flow of money for the growth of the economy. In this regard, government of UAE should develop and maintain sound policies to enhance Islamic banking sector to promote economic growth of the country. In contrast, the results do not show the same relation for FDI, where the relationship is bi-directional. It means that UAE have an efficient banking system and a dynamic economy, which creates a good atmosphere for foreign direct investment and through foreign direct investment come in home economy.

\section{References}

1. Abdoh, O., and Omar, A. (2012). Islamic banking and economic growth: the Indonesian experience. International Journal of Islamic and Middle Eastern Finance and Management, 5(1), 35-47.

2. Abu-Bader, S., and Abu-Qarn, A. S. (2008). Financial Development and Economic Growth: The Egyptian Experience. Journal of Policy Modelling, 30, 887-898.

3. Bashir, and Hasan, M. (2003). Financial Development and Economic Growth in Some Muslim Countries, In the Fifth International Conference on Islamic Economic and Finance: Sustainable Development and Islamic Finance in Muslim Countries.

4. Beck, T., Levine, R. (2004). Finance and the Sources of Growth. Journal of Financial Economics, 58, 261-300.

5. Central bank report. (2015). Economic report of UAE. Retrived from http://www.centralbank.ae/pdf/reports/CBUAEAnnualReport-2015_En.pdf(17 Oct., 2016).

6. Emirates Diary report. (2015). Retrived from http://emiratesdiary.com/uae-tips/list-of-islamic-banks-inuae\#ixzz4OOVVgTyg (Oct. 15, 2016).

7. Furqani, H., and Mulyany, R. (2009). Islamic banking and economic growth: empirical evidence from Malaysia, Journal of Economic Cooperation and Development, 30(2), 59-74.

8. Goldsmith, R. (1969). Financial Structure and Economic Growth in Advanced Countries. National Bureau Committee for Economic Research, Capital Formation and Economic Growth, Princeton, University Press.

9. Granger, C. W. J. (1987). Developments in the study of co-integrated Economic Variables. Oxford Bulletin of Economics and Statistics, 48, 213-248.

10. Johansen, S., and Juselius, K. (1990). Maximum likelihood estimation and inference on cointegration with application to the demand for money. Oxford Bulletin of Economics and Statistics, 52, 169-210.

11. Kar, M. S., and Agir, H. (2011). Financial Development and Economic Growth nexus in the MENA countries: Bootstrap Panel Granger Causality Analysis. Econometric Modelling, 28(2), 685-693.

12. King, and Levine. (1993). Finance and Growth: Schumpeter Might be Right Robert. The Quarterly Journal of Economics, 108(3), 717-737.

13. Lucas, R. E. (1988). On the Mechanics of Economic Development. Journal of Monetary Economics, 22(2), 3-42.

14. Tabash, M., and Dhankar, S. (2014). The Relevance of Islamic Finance Principles in Economic Growth, International Journal of Emerging Research in Management \&Technology, 3(2).

15. Tabash, M., and Dhankar, S. (2015). Islamic banking and Economic Growth: A cointegration. Romanian Economic Journal, 17(53), 61-90.

16. Tajgardoon, and Noormohamadi. (2012). Foreign Direct Investment and Islamic Banking: A Granger Causality Test. Economics and Finance Review, 2(5), 08-13.

17. McKinnon, R. I. (1973). Money and Capital in Economic Development. The Brookings Institutions, Washington, DC.

18. Narayan, P. K., and Prasad, A. (2008). Electricity consumption-real GDP causality nexus: evidence from a bootstrapped causality test for 30 OECD countries. Energy Policy, 36, 910-18.

19. Odhiambo, N. M. (2011). Tourism Development and Economic Growth in Tanzania: Empirical Evidence from the ARDLBounds Testing Approach. Economic Computation and Economic Cybernetics Studies and Research, 45(3), 71-83.

20. Patrick, H. T. (1966). Financial development and economic growth in developing countries. Economic Development and Cultural Change, 14(2), 174-89.

21. Robinson, J. (1952). The Generalization of the General Theory in the Rate of Interest and Other Essays. London: Macmillan.

22. Shaw, E. S. (1973). Financial Deepening in Economic Development. Oxford University Press, New York.

23. Schumpeter, J. A. (1934). The Theory of Economic Development. Cambridge, MA, Harvard University Press.

24. The Size of the Islamic Finance Market Report. (2016). Retrived from https://www.islamicfinance.com/2015/05/sizeislamic-finance-industry/\# ftn1 (Oct. 28, 2016).

25. World Bank report. (2015). Retrived from http://www.worldbank.org/en/topic/financialsector/brief/islamic-finance (Oct. 22, 2016).

26. World Fact Book report. (2014). United Arab Emirates report. Retrived from https://www.cia.gov/library/publica (Dec., 2016). 